\title{
CHARACTERIZATION OF YELLOW LATOSOLS (OXISOLS) OF SERRA DO QUILOMBO, IN PIAUÍ STATE SAVANNA WOODLANDS - BRAZIL ${ }^{1}$
}

\author{
ROSSANNA BARBOSA PRAGANA ${ }^{2 *}$, VALDOMIRO SEVERINO DE SOUZA JUNIOR ${ }^{3}$, REGIANA DOS SANTOS \\ MOURA $^{4}$, JORDÂNIA MEDEIROS SOARES ${ }^{5}$
}

\begin{abstract}
The savanna woodlands of Piauí state has great economic importance since it is an area for agricultural expansion, being the fourth most important of Brazil and the first from Brazilian Northeastern. The area accounts for $5.9 \%$ of the Brazilian savanna woodlands and $36.9 \%$ of the Northeastern savanna, covering $46 \%$ of the Piauí state area, in a total of 11.5 million hectares. The goal of this research was to study pedoenvironments of Serra do Quilombo region, which is in Piauí state savanna, as well as identifying existing soil classes, according to the Brazilian System of Soil Classification - SiBCS. Soil identification consisted in characterizing soil profiles along a transect, assessing in-field conditions and collecting soil samples, in areas of native vegetation. The samples were gathered from three distinct points, being two at the edges and one at the center of the plateau. Soil analyses were carried out with samples collected from each horizon through trench digging up to a 2-m depth. Morphological, physical, chemical and mineralogical characterizations were performed for each soil profile, along with an evaluation of the effect of pedogenic factors on their formation and development. All soils under study were formed with source materials of the same geological formation; however, each rock has a distinct contribution to the process, involving sandstones and shales. The characteristics observed in the soil from Serra do Quilombo have no difference from the pattern found in the Brazilian plateaus, and soil profiles were classified as dystrophic clayey Yellow Latosols (Oxisols), according to the SiBCS.
\end{abstract}

Key words: Soil classification. Latosolization. Pedogenesis.

\section{CARACTERIZAÇÃO DE LATOSSOLOS AMARELOS DA SERRA DO QUILOMBO NO CERRADO PIAUIENSE}

\begin{abstract}
RESUMO - O Cerrado piauiense tem grande importância econômica por ser uma área de expansão agrícola, sendo o quarto mais importante do Brasil e o primeiro do Nordeste. Representa 5,9 \% do cerrado brasileiro, $36,9 \%$ do nordestino e $46 \%$ da área total do Estado do Piauí, ao todo são 11,5 milhões de hectares. O objetivo desta pesquisa foi estudar os pedoambientes da Serra do Quilombo, localizada no cerrado piauiense, e identificar as classes de solos existentes de acordo com o Sistema Brasileiro de Classificação de Solos. A identificação dos solos consistiu na caracterização de perfis de solo ao longo de um transecto, com a avaliação e coleta de solos em áreas de vegetação nativa, em três pontos, sendo nas extremidades e no centro da chapada. A análise dos solos e a coleta de amostras de cada horizonte dos três perfis de solo foram realizadas mediante abertura de trincheiras, com $2 \mathrm{~m}$ de profundidade. Foi feita a caracterização morfológica, física, química e mineralógica de cada perfil dos solos, juntamente com avaliação da influência dos fatores pedogenéticos na sua formação e evolução. Os solos estudados são formados de materiais de origem da mesma formação geológica, no entanto, com diferentes contribuições das diversas rochas, envolvendo arenitos e folhelhos. As características dos solos verificadas na Serra do Quilombo não diferem do padrão comumente observado nas chapadas do Brasil, sendo os perfis classificados como LATOSSOLOS AMARELOS Distróficos argissólicos, de acordo com o Sistema Brasileiro de Classificação de Solos.
\end{abstract}

Palavras-chave: Classificação de solo. Latossolização. Pedogênese.

\footnotetext{
*Corresponding author

${ }^{1}$ Received for publication in $10 / 22 / 2014$; accepted in 06/16/2016.

Paper extracted from the doctoral thesis of the first author.

${ }^{2}$ Academic Unit of Serra Talhada, Universidade Federal Rural de Pernambuco, Serra Talhada, PE, Brazil; rossannapragana@yahoo.com.br.

${ }^{3}$ Department of Agronomy, Universidade Federal Rural de Pernambuco, Recife, PE, Brazil; valdomiro.souzajunior@ufrpe.br.

${ }^{4}$ Department of agricultural engineering, Universidade Federal do Recôncavo da Bahia, Cruz das Almas, BA, Brazil; regianna.ufpi@gmail.com.

${ }^{5}$ Department of Agronomy, Universidade Federal de Goiás, Goiânia, GO, Brazil; jjordanny@hotmail.com.
} 


\section{INTRODUCTION}

The savanna environment of Piauí state has great economic importance since it is an area for agricultural expansion, which has provided leadership of gross domestic product growth to the soybean producing cities in Piauí for the last 20 years. The savanna macro-region of this state occupies third place in Gross Domestic Product (GDP) of the state, with a relative share of $11.6 \%$ of GDP (NEIVA et al., 2007). The area stands for 5.9 $\%$ of the Brazilian savanna, $36.9 \%$ of the Northeastern region and covers $46 \%$ of the entire state (FUNDAÇÃO CEPRO, 1992).

Understanding soil formation is imperative to subsidizing decision making regarding its management. Relief causes changes in soil properties at a varied scale, such as affecting soil depths. Furthermore, weather conditions are also liable to influence such variations (CAMPOS et al., 2007).

Casseti et al. (1994) evaluated geomorphological traits of latosol formation in central Brazil that are similar to those observed in soils of the savanna region in Piauí state. The authors postulated that plains landscapes are associated to dry climates. Ancient morphoclimatic processes, whose disaggregated material was resulted from a dry and semi-arid period within Pennsylvanian, can explain either relief shape or correlate deposits.

The effects of Pennsylvanian hot climate are observed through flatness of the extensive landscapes. These conditions favored weathering of rocks, whose detritus dragged by torrential rains, typical semiarid, filling slumps throughout the terrain, resulting in extensive flat surfaces (CASSETI et al., 1994). Nowadays, climate is considered sub-humid, with an annual rainfall average of $1000 \mathrm{~mm}$, which is responsible for drying out the flat surfaces.

Several studies have pointed out that latosols cover the planning surfaces, being one of the most common soils of savanna plateaus of flat to gently undulating relief, over a vast area in Brazil (FERREIRA, et al., 2010; KER, 1998; FERREIRA, et al., 2010).

According to Jacomine et al. (1986), soils on upper tabular surfaces are classified as dystrophic Yellow Latosols (Oxisols), whose Bw horizon shows a clay activity smaller than $13 \mathrm{cmolc} \mathrm{kg}^{-1}$ of clay, $\mathrm{Ki}$ molecular ratio higher than most of the tropical Latosols (Oxisols) (1.8 and 2.2), $\mathrm{Kr}$ molecular ratio greater than or equal to 1.40 ; rate of $\mathrm{Fe}_{2} \mathrm{O}_{3}$ from sulfuric attack below $10 \%$; ratio between $\mathrm{Fe}_{2} \mathrm{O}_{3}$ rate and the sum of oxides from sulfuric attack being less than 0.20 , besides of showing predominance of kaolinite within the clay fraction.

Other pedogenic traits related to latosols are cohesion and acric nature. Cohesion is a typical characteristic of subsurface horizons, which are hard to much hard when dried, becoming friable or solid when moist. Its acric feature is characterized by showing a B-horizon of low cation retention and clay CEC too low, besides being oxidic, since they have already undergone kaolinitic phase (SANTOS et al., 2013a; ALLEONI; CAMARGO, 1995).

This research focused on studying the pedoenvironments of soil in Serra do Quilombo, a place located within Piauí state savanna region, as well as identify the existing soil classes classifying them according to the Brazilian System of Soil Classification.

\section{MATERIAL AND METHODS}

Serra do Quilombo is located in southwestern Piauí state, between the cities of Uruçuí and Bom Jesus, being included within the savanna region of the state. Local climate is hot and humid tropical with a well-defined dry season (Aw type according to Köppen classification). Annual averages of temperature and rainfall have been $26^{\circ} \mathrm{C}$ and 1,000 mm, respectively (AGUIAR; GOMES, 2004).

The predominant relief of Serra do Quilombo can be classified as a tabular plateau with flat landscape, whose shall not exceed $3 \%$, lying at altitudes of 400-500 meters (JACOMINE et al., 1986). Regarding the geological formation, rocks of Piauí Group are prevalent, being made up of pinkish medium sandstones interlayered with red and green siltstones, reddish sandstones interbedded with beds and laminae of red siltstones, thin beds of limestones and evaporites (SANTOS; CARVALHO, 2009). Associations of sandstones and shales make up the lithological unit (AGUIAR; GOMES, 2004). Moreover, the area is covered by a semideciduous savanna-like vegetation, called cerrado, with caatinga to cerrado transitions areas along the slopes.

The soils were identified by collecting samples along a transect observing and gathering the soil at three points within the Serra do Quilombo, 30 $\mathrm{km}$ apart from each other, as shown in Figure 1. These sampling points were set in fields of native vegetation, one at each end of the plateau and a third one in the center of it, the area has a length of $70 \mathrm{~km}$. The three studied soil profiles are located along a 59-km-long transect, being: Profile $1(\mathrm{P} 1)$ at $9^{\circ} 18^{\prime}$ $00^{\prime \prime} \mathrm{S}$ latitude, $44^{\circ} 37^{\prime} 33^{\prime}$ 'W longitude and $517 \mathrm{~m}$ altitude; Profile $2(\mathrm{P} 2)$ at $9^{\circ} 16^{\prime} 0.24^{\prime \prime}$ 'S latitude, $44^{\circ}$ 52' 40.6' W longitude and $652 \mathrm{~m}$ altitude; and Profile 3 (P3) at $9^{\circ} 10^{\prime} 40.85^{\prime}$ ' S latitude, $45^{\circ} 07^{\prime}$ 07 ' $\mathrm{W}$ longitude and $569 \mathrm{~m}$ altitude. $\mathrm{P} 2$ and $\mathrm{P} 3$ are part of a statutory reserve belonging to soybean farms; yet P1 has been eventually used for extensive livestock production. 


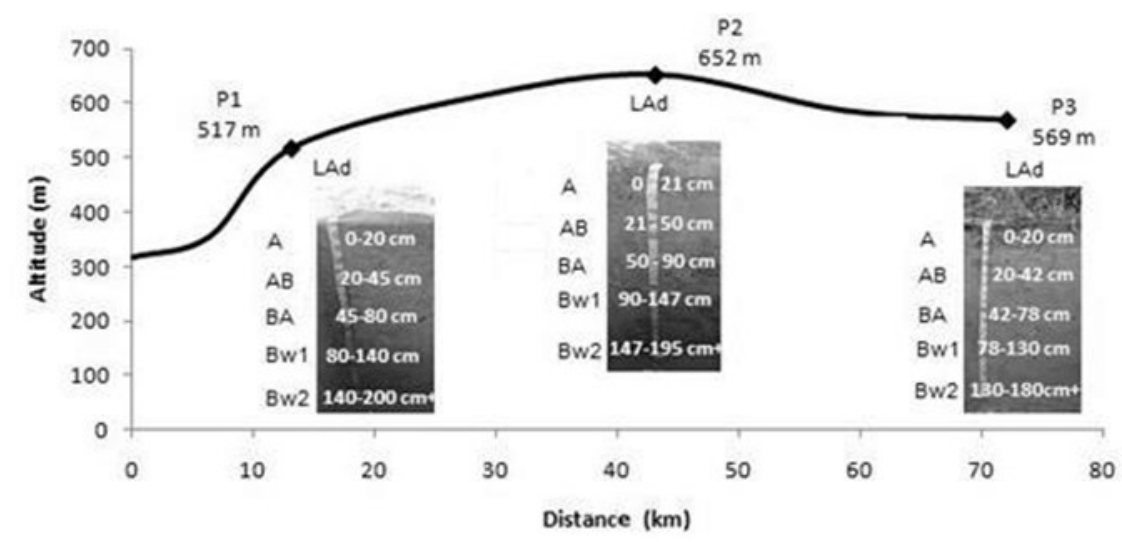

Figure 1. Soil profiles along a transect (P1 to P3).

Soil morphological evaluation and sampling were carried out through trench digging, following recommendations of Santos et al. (2013b). Three deformed and three non-deformed soil samples were collected from each horizon of the assessed soil profiles, making 90 samples. They were used for physical, chemical and mineralogical characterization of the soil. As for identification and classification to the field, criteria established by the Brazilian System of Soil Classification (SiBCS) were followed (SANTOS et al, 2013a).

After preparation of the samples (air-dried fine earth - ADFE), sieving analysis was performed, evaluating the clay content dispersed in water (CDW), particle density (DP) and bulk density (DB). From the results, clay flocculation degree (CF), silt and clay ratio, and total porosity were calculated by the ratio between soil and particle densities, as stated by Donagema et al. (2011).

Likewise, soil chemical analyzes followed the recommendations of Donagema et al. (2011), determining $\mathrm{pH}$ in $\mathrm{H}_{2} \mathrm{O}$ and in $\mathrm{KCl} ; \mathrm{Ca}^{+2} ; \mathrm{Mg}^{+2} ; \mathrm{K}^{+}$; $\mathrm{Na}^{+} ; \mathrm{Al}^{+3}$; potential acidity and total organic carbon (TOC). Next, exchangeable hydrogen, base sum, base saturation, cation exchange capacity, aluminum saturation and $\mathrm{DpH}$ were estimated by the results previously obtained.

Silica, aluminum, iron, titanium and manganese were extracted by sulfuric acid digestion (DONAGEMA et al., 2011) made in soil samples from $\mathrm{A}$ and $\mathrm{Bw} 2$ horizons of the three profiles. Hereupon, contents of each element were converted into oxide concentrations. The molecular relationships $\mathrm{Ki}$ and $\mathrm{Kr}$ were calculated by equations 1 and 2.

$$
k i=[(\% \operatorname{SiO} 2 \times 1.697) / \% \text { Al2O3] } \quad \text { Eq. } 1
$$

$K r=[(\% \mathrm{SiO} 2 \times 1.697) / \% \mathrm{Al2O3}+(\% \mathrm{Fe} 203 \times 0,64)] \mathrm{Eq} .2$

The clay fraction mineralogical analysis was carried out through X-ray diffraction (XRD), using the Bw2 horizon samples (JACKSON, 1979). The diffractograms were obtained using a Shimadzu $\mathrm{X}$-ray diffractometer, operating at $40 \mathrm{kV}$ and $20 \mathrm{~mA}$, with $\mathrm{Cu} \mathrm{K \alpha}$ radiation and graphite monochromator. Samples were prepared and analyzed in powder form (non-oriented), at a scanning range of 5 to $70^{\circ}(2 \theta)$ and speed of $1.5^{\circ}(2 \theta)$ per min.

After the pre-treatments for removal of carbonates, iron oxides and organic matter, samples of clay were saturated with $\mathrm{KCl}$ at room temperature and heated to $550{ }^{\circ} \mathrm{C}$ (K25 and K550 samples) as outlined by Jackson (1979), being saturated by $\mathrm{MgCl}_{2}$ ( $\mathrm{Mg}$ sample). The samples were analyzed as smears on glass slides ('oriented mount') within a scanning of 3 to $35^{\circ}(2 \theta)$ and recording speed of $1.5^{\circ}$ (20) per min.

Interpretation of the diffractograms and identification of clay fraction mineral were performed based on spacing between plans (d) and behavior of diffraction reflections, as disclosed by Jackson (1979), Brindley \& Brown (1980), and Moore \& Reynolds (1989).

\section{RESULTS AND DISCUSSION}

Table 1 shows the soil classification of each profile. P1 was classified as a dystrophic Yellow Latosol (Oxisol) of medium texture, with A moderate horizon, cerrado phase, flat terrain. The soil profiles $\mathrm{P} 2$ and $\mathrm{P} 3$ were similarly rated, except for the texture that was considered clayey. 
Table 1. Morphological characterization profiles of Yellow Latosols (Oxisols).

\begin{tabular}{|c|c|c|c|c|c|c|c|c|}
\hline \multirow{2}{*}{$\begin{array}{c}\text { Hori- } \\
\text { zons }\end{array}$} & \multirow{2}{*}{$\begin{array}{l}\text { Depth } \\
(\mathrm{cm})\end{array}$} & \multirow{2}{*}{$\begin{array}{l}\text { Moist color } \\
\text { (Munsell) }\end{array}$} & \multirow[t]{2}{*}{ Structure $^{1}$} & \multicolumn{3}{|c|}{ Consistency $^{2}$} & \multirow[t]{2}{*}{ Boundary $^{3}$} & \multirow[t]{2}{*}{ Roots } \\
\hline & & & & dry & moist & wet & & \\
\hline \multicolumn{9}{|c|}{ Profile P1 - dystrophic clayey Yellow Latosols } \\
\hline A & $0-20$ & $7.5 \mathrm{YR} 4 / 2$ & $\mathrm{sab} / \mathrm{f} / \mathrm{w} \mathrm{gr} / \mathrm{f} / \mathrm{mo}$ & shd & vfr & spl spg & $\operatorname{grd} / \mathrm{sm}$ & many \\
\hline $\mathrm{AB}$ & $20-45$ & $7.5 \mathrm{YR} 5 / 4$ & $\mathrm{sab} / \mathrm{vff} / \mathrm{w}$ & shd & vfr & spl spg & $\operatorname{grd} / \mathrm{sm}$ & many \\
\hline BA & $45-80$ & $7.5 \mathrm{YR} 5 / 6$ & $\mathrm{sab} / \mathrm{vff} / \mathrm{w}$ & hd & vfr & spl spg & dif. e pl & common \\
\hline Bw1 & $80-140$ & $7.5 \mathrm{YR} 5 / 6$ & $\mathrm{sab} \mathrm{m} \mathrm{po} / \mathrm{vff} / \mathrm{w}$ & shd hd & vfr & spl spg & dif. e pl & common \\
\hline Bw2 & $140-200+$ & $7.5 \mathrm{YR} 5 / 8$ & $\mathrm{sab} / \mathrm{vff} / \mathrm{w}$ & shd hd & vfr & spl spg & & few \\
\hline \multicolumn{9}{|c|}{ Profile P2 - dystrophic clayey Yellow Latosols } \\
\hline A & $0-21$ & $7.5 \mathrm{YR} 4 / 2$ & $\mathrm{sab} / \mathrm{f} / \mathrm{w} \mathrm{gr} / \mathrm{f} / \mathrm{mo}$ & hd & vfr & spl spg & $\operatorname{grd} / \mathrm{sm}$ & many \\
\hline $\mathrm{AB}$ & $21-50$ & $7.5 \mathrm{YR} 5 / 4$ & $\mathrm{sab} / \mathrm{vff} / \mathrm{w}$ & hd & vfr & spl spg & $\operatorname{grd} / \mathrm{sm}$ & many \\
\hline BA & $50-90$ & $7.5 \mathrm{YR} 5 / 6$ & sab m po/vff/w & hd & vfr & spl spg & dif. e sm & common \\
\hline Bw1 & $90-147$ & $7.5 \mathrm{YR} 5 / 6$ & sab m po/vff/w & hd & vfr & spl spg & dif. e sm & few \\
\hline Bw2 & $147-195+$ & $7.5 \mathrm{YR} 5 / 8$ & sab m po/vf f/w & shd & vfr & spl spg & & few \\
\hline \multicolumn{9}{|c|}{ Profile P3 - dystrophic clayey Yellow Latosols } \\
\hline A & $0-20$ & $10 \mathrm{YR} 5 / 2$ & $\begin{array}{l}\mathrm{sab} / \mathrm{f} \mathrm{md} / \mathrm{w} \mathrm{gr} / \mathrm{f} \mathrm{md} / \\
\mathrm{mo}\end{array}$ & shd & vfr & spl spg & $\operatorname{grd} / \mathrm{sm}$ & many \\
\hline $\mathrm{AB}$ & $20-42$ & $7.5 \mathrm{YR} 4 / 4$ & $\mathrm{ab} / \mathrm{md}$ vf f/ w & hd & $\mathrm{fr}$ & spl spg & $\operatorname{grd} / \mathrm{sm}$ & many \\
\hline BA & $42-78$ & $7.5 \mathrm{YR} 4 / 6$ & $a b / v f f / w$ & hd & fr & pl.pg & dif. e sm & many \\
\hline Bw1 & $78-130$ & 7.5 YR 5/6 & $a b / v f f / w$ & hd & vfr & pl. pg & dif. e sm & common \\
\hline Bw2 & $130-180+$ & 7.5 YR $5 / 8$ & $a b \mathrm{~m} \mathrm{po} / \mathrm{vff} / \mathrm{w}$ & shd & vfr & pl.pg & & few \\
\hline
\end{tabular}

${ }^{1}$ (Form/Size/Resistance) - Form: gr - granular, sab - subangular blocks, ab - angular blocks, $\mathrm{m}$ - massive, po - porous; Size: f - fine, vf - very fine, md - medium ; Resistênce: w - weak, mo - moderate; ${ }^{2}$ Dry: hd - hard, shd - slightly hard ; Moist: fr friable, vfr - very friable; Wet: pl - plastic, spl - slightly plastic, pg - sticky, spg - slightly sticky ${ }^{3}$ sm - smoot, dif - Diffuse, grd - gradual.

Despite the 60-km distance and 135-m slope between the first and last profile, unevenness along the transect are minimal and soil are quite similar in characteristics. Relief is one of the factors of soil formation with strong impact on spatial variability of soil properties throughout landscape (CEDDIA et al, 2009). Once the studied area has a flat relief, the soils have no striking variability regarding their attributes. The soils along the studied transect are quite deep, with a B latosolic horizon deeper than $200 \mathrm{~cm}$, and texture ranging from medium to clayey, which are compliant with the nature of source materials (sandstones and shales).

In general, all profiles varied little in color, with slight difference between horizons, confirming the homogeneity of the area. The A horizon of all profiles was identified as moderate. The wetting and drying cycles on this horizon favored the structuring of sub-angular and granular blocks.

The wet color of Bw horizon, according to the Munsell color chart, was of 7.5 YR hue with value of 5 and chroma between 6 to 8 (dark brown) for the three profiles, which represents a major morphological attribute for soil sub-classification (SANTOS et al, 2013a). All horizons, in the three profiles, showed yellowish hue values, signaling goethite, which had been confirmed through the mineralogical analysis.

The B latosolic horizons ( $\mathrm{Bw} 1$ and 2) of all profiles showed prevalence of sub-angular blocks; nevertheless, a granular structure is mostly common in Brazilian savanna regions due to the presence of oxides, mainly in Oxisols, which are much weathered (CARDUCCI et al. 2011). The presence of kaolinite in the analyzed soil favored block structuring (GHIDIN et al., 2006). For Ker (1998), the absence of gibbsite may be the main cause of a sub-angular block structure weakly developed with low stability in water, which is characteristic of Yellow Latosols (Oxisols). The consistency of these soils differs from cohesive latosols because cohesiveness is a typical pedogenic trait of subsurface horizons, overall between 30 and $70 \mathrm{~cm}$ deep, which are very hard to extremely hard when 
dry, becoming friable or firm when wet (SANTOS et al., 2013). In this research, soils showed consistency between slightly hard to hard when dry, not fitting to the cohesive latosols.

Sieving analysis revealed a dominance of sand fraction in all profiles and horizons. Table 2 shows increasing clay contents with depth in all profiles. Furthermore, grain size distribution varied along transect, starting with lower amount of clay in P1 that increased in P3. These changes clearly demonstrate the influence of source material on soil texture. Sandstone contribution is mostly seen at the beginning of the hill slope (P1), decreasing throughout transect when an increased shale contribution favors a much clayey texture (P2 and P3).

Table 2. Physical characterization profiles of Yellow Latosols (Oxisols).

\begin{tabular}{|c|c|c|c|c|c|c|c|c|c|c|c|}
\hline \multirow[t]{3}{*}{ Horizons } & \multicolumn{2}{|c|}{ Sand } & Silt & Clay & Textural & $\mathrm{CDW}^{2}$ & $\mathrm{CF}^{3}$ & \multirow{3}{*}{$\begin{array}{l}\text { Silt/ } \\
\text { clay }\end{array}$} & \multirow{3}{*}{\multicolumn{2}{|c|}{$\begin{array}{l}\mathrm{DB}^{4} \quad \mathrm{DP}^{5} \\
----\mathrm{Mg} \mathrm{m}^{-3}----\end{array}$}} & \multirow{3}{*}{$\begin{array}{c}\mathrm{TP}^{6} \\
\mathrm{~m}^{3} \mathrm{~m}^{-3}\end{array}$} \\
\hline & Fine & Coarse & & & class $^{1}$ & & & & & & \\
\hline & \multicolumn{5}{|c|}{---------------g kg kg $^{-1}---------------$} & $\mathrm{g} \mathrm{kg}^{-1}$ & $\%$ & & & & \\
\hline \multicolumn{12}{|c|}{ Profile P1 - dystrophic clayey Yellow Latosols } \\
\hline A & 442 & 324 & 66 & 168 & sandy loan & 83 & 51 & 0.39 & 1.23 & 2.63 & 53 \\
\hline $\mathrm{AB}$ & 481 & 245 & 59 & 214 & san. cla. lo & 123 & 42 & 0.28 & 1.31 & 2.53 & 48 \\
\hline BA & 444 & 222 & 63 & 271 & san. cla. lo & 178 & 34 & 0.23 & 1.28 & 2.56 & 50 \\
\hline Bw1 & 403 & 184 & 78 & 335 & san. cla. lo & 0 & 100 & 0.23 & 1.24 & 2.70 & 54 \\
\hline Bw2 & 396 & 182 & 94 & 329 & san. cla. lo & 0 & 100 & 0.29 & 1.26 & 2.60 & 51 \\
\hline \multicolumn{12}{|c|}{ Profile P2 - dystrophic clayey Yellow Latosols } \\
\hline A & 429 & 294 & 56 & 221 & san. cla. lo & 110 & 50 & 0.25 & 0.96 & 2.56 & 62 \\
\hline $\mathrm{AB}$ & 464 & 232 & 47 & 256 & san. cla. lo & 156 & 39 & 0.18 & 1.22 & 2.63 & 54 \\
\hline $\mathrm{BA}$ & 359 & 193 & 52 & 395 & sandy clay & 219 & 45 & 0.13 & 1.31 & 2.51 & 48 \\
\hline Bw1 & 360 & 197 & 48 & 395 & sandy clay & 2 & 100 & 0.12 & 1.23 & 2.70 & 55 \\
\hline Bw2 & 377 & 189 & 63 & 370 & sandy clay & 2 & 99 & 0.17 & 1.12 & 2.70 & 58 \\
\hline \multicolumn{12}{|c|}{ Profile P3 - dystrophic clayey Yellow Latosols } \\
\hline A & 371 & 304 & 63 & 262 & san. cla. lo & 117 & 56 & 0.24 & 0.84 & 2.60 & 68 \\
\hline $\mathrm{AB}$ & 389 & 237 & 55 & 319 & san. cla. lo & 177 & 44 & 0.17 & 1.27 & 2.64 & 52 \\
\hline BA & 331 & 219 & 44 & 406 & sandy clay & 221 & 46 & 0.11 & 1.17 & 2.63 & 56 \\
\hline Bw1 & 337 & 205 & 40 & 417 & sandy clay & 1 & 100 & 0.10 & 1.18 & 2.53 & 53 \\
\hline Bw2 & 342 & 159 & 87 & 413 & sandy clay & 0 & 100 & 0.21 & 1.13 & 2.70 & 58 \\
\hline
\end{tabular}

${ }^{1}$ san. cla. lo - sandy clay loan; ${ }^{2} \mathrm{CDW}$ - water-dispersible clay; ${ }^{3} \mathrm{CF}$ - clay flocculation degree; ${ }^{4} \mathrm{DB}$ - bulk density; ${ }^{5} \mathrm{DP}$ - particle density e ${ }^{6} \mathrm{TP}-$ total porosity.

Textural variation in depth associated to a low silt and clay ratio ( 0.10 to 0.39$)$, reveal the degree of weathering of the soils, thus allowing correspondence with Latosol class; yet textural ratios above 1.4 make them to become Argisols (Ultisols) (SANTOS et al., 2013a).

Considering the three profiles, CDW decreased in depth, with values from 0 to $2 \%$ in $\mathrm{Bw}$ horizons. According to Alleoni and Camargo (1994), one of the factors favoring higher CDWs in the surface layer is its largest OC content, because organic matter is a major source of negative charges in soil (BALDOTT; VELLOSO, 2014). Whereas the CDW behaves in an opposite manner to $\mathrm{CF}$, generally, lower density of negative charges increases flocculation and, therefore, lesser mutual repulsion between particles of the same electric field. This way, $\mathrm{Bw}$ horizons are further flocculated by owning lower density of negative charges, which can be by decreasing $\mathrm{T}$ values if compared to surface horizons.

The $\mathrm{Db}$ ranged from 0.84 a $1.31 \mathrm{Mg} \mathrm{m}^{-3}$ among the studied profiles. As claimed by Ferreira et al. (2010), Db in surface horizons of latosols under native vegetation is low, typically less than $1.0 \mathrm{Mg}$ $\mathrm{m}^{-3}$. Among the analyzed profile, solely A horizon of
P1 had a value above $1.0 \mathrm{Mg} \mathrm{m}^{-3}$. This area underwent eventual animal trampling, which might have raised $\mathrm{Db}$ in $\mathrm{A}$ horizon (moderate); moreover, this profile has lower TOC and an increased concentration of sand.

In the three profiles, $\mathrm{Db}$ of $\mathrm{A}$ horizon was inferior to the others, which is due to a higher TOC found in this horizon. Knowing that density combines mass and volume, organic matter, which is rich in organic carbon, reduces soil weight, consequently, its density. Regarding the $\mathrm{Dp}$, it is noteworthy that increasing values throughout the profiles can be explained by lower contents of organic matter in subsurface horizons. Moreover, higher amounts of mineral fraction, mainly finer ones, as it increases the depth may influence these results. The $\mathrm{Pt}$ was lower than $0.60 \mathrm{~m}^{3} \mathrm{~m}^{-3}$ in all evaluated horizons, except for $\mathrm{P} 2$ and $\mathrm{P} 3$, since they showed lower $\mathrm{Db}$ (Table 2) and larger OC contents. The average $\mathrm{Pt}, 0.55 \mathrm{~m}^{3} \mathrm{~m}^{-3}$, combined with a medium texture gives these soils a fluid drainage ability.

Increased Ds and reduced Pt when comparing nearby horizons are characteristic of cohesive horizons. Lima Neto et al. (2009) found Db ranges between 1.45 and $1.54 \mathrm{~kg} \mathrm{dm}^{-3}$ together with smaller 
values of $\mathrm{Pt}$, between 0.41 and $0.44 \mathrm{~m}^{3} \mathrm{~m}^{-3}$, in cohesive horizons as compared to the others for Yellow Latosols (Oxisols) from Coastal Uplands of Alagoas state (Brazil). Likewise, Souza et al. (2004), studying the same type soils in Cruz das Almas - BA (Brazil), reported a Db of $1.70 \mathrm{~kg} \mathrm{dm}^{-3}$ and $\mathrm{Pt}$ of $31.5 \mathrm{~m}^{3} \mathrm{~m}^{-3}$. In this study, $\mathrm{Db}$ did not exceed $1.31 \mathrm{~kg} \mathrm{dm}^{-3}$ and $\mathrm{Pt}$ ranged from 0.48 to 0.56 $\mathrm{m}^{3} \mathrm{~m}^{-3}$ (Table 2); such values point out a lack of cohesive layers in the assessed soils.

The $\mathrm{pH}$ values were relatively low, but increasing toward depth (Table 3), being regarded as a strongly acidic soil (SANTOS et al, 2013a). This attribute reflects local weather conditions, wherein a mean rainfall of $1000 \mathrm{~mm}$ would favors base leaching and then soil acidification. For the three profiles, $\Delta \mathrm{pH}$ was negative, showing a negative net charge, kaolinitic nature and chemical paucity of these soils (MELO et al., 2006).

The base sum (S) in A horizon was higher for P2 and P3 since they showed a clay content greater than $\mathrm{P} 1$, increasing thus cation adsorption capacity.
However, $\mathrm{Na}^{+}$and $\mathrm{K}^{+}$contents were much low, confirming the leaching favored by climatic conditions. At high temperatures, intense rainfalls and good drainage conditions, mica and feldspars are transformed into kaolinite (ORRUTÉA et al., 2012) and $\mathrm{K}^{+}$and $\mathrm{Na}^{+}$are easily leached. It is worth emphasizing that these soils are originated from sandstones, which is generally a poor rock on basic elements.

The contents of $\mathrm{Al}^{3+}$ and $\mathrm{H}^{+}$decreased with depth, wherein A horizons showed higher values compared to the sub-surface ones. It might have occurred due to formation of organometallic complexes with $\mathrm{Al}^{3+}$, which raises organic matter resistance reducing $\mathrm{Al}^{3+}$ losses, as already reported by Inda Junior et al. (2007). Aluminum saturation (m) was higher in the surface horizons, corroborating the results obtained by Ferreira et al. (2010), however, these soils show no alitic character nor aluminic since the $\mathrm{Al}^{3+}$ contents in diagnostic horizons were below to 4 cmolc $\mathrm{kg}^{-1}$ (SANTOS et al., 2013a).

Table 3. Chemical characterization profiles of Yellow Latosols (Oxisols).

\begin{tabular}{|c|c|c|c|c|c|c|c|c|c|c|c|c|c|}
\hline \multirow[t]{2}{*}{ Horizons } & \multicolumn{3}{|c|}{$\mathrm{pH}(1: 2,5)$} & \multicolumn{5}{|c|}{ Chemical composition $\left(\mathrm{cmol}_{\mathrm{c}} \mathrm{kg}^{-1}\right)$} & \multirow[b]{2}{*}{$\mathrm{Al}^{3+}$} & \multirow[b]{2}{*}{$\mathrm{CEC}^{1}$} & \multirow[b]{2}{*}{$\begin{array}{c}\text { Ba sat }^{2} \\
(\%)\end{array}$} & \multirow[b]{2}{*}{$\begin{array}{l}\mathrm{m}^{3} \\
(\%)\end{array}$} & \multirow[b]{2}{*}{$\begin{array}{c}\mathrm{TOC}^{4} \\
\text { dag kg }^{-1}\end{array}$} \\
\hline & $\mathrm{H}_{2} \mathrm{O}$ & $\mathrm{KCl}$ & $\Delta \mathrm{pH}$ & $\mathrm{Ca}^{2+}+\mathrm{Mg}^{2+}$ & $\mathrm{K}^{+}$ & $\mathrm{Na}^{+}$ & Base sum & $\mathrm{H}^{+}$ & & & & & \\
\hline \multicolumn{14}{|c|}{ Profile P1 - dystrophic clayey Yellow Latosols } \\
\hline A & 4.5 & 3.5 & -1.0 & 0.4 & 0.02 & 0.01 & 0.4 & 3.9 & 1.4 & 5.6 & 7 & 78 & 1.14 \\
\hline $\mathrm{AB}$ & 5.0 & 3.9 & -1.1 & 0.5 & 0.00 & 0.01 & 0.5 & 1.3 & 0.7 & 2.5 & 21 & 58 & 0.56 \\
\hline $\mathrm{BA}$ & 5.3 & 4.0 & -1.3 & 0.4 & 0.00 & 0.01 & 0.4 & 0.8 & 0.7 & 1.9 & 21 & 64 & 0.42 \\
\hline Bw1 & 5.5 & 4.2 & -1.3 & 0.6 & 0.00 & 0.01 & 0.6 & 0.9 & 0.4 & 1.8 & 31 & 42 & 0.38 \\
\hline Bw2 & 5.6 & 4.3 & -1.3 & 0.7 & 0.00 & 0.01 & 0.7 & 0.6 & 0.5 & 1.7 & 40 & 40 & 0.36 \\
\hline \multicolumn{14}{|c|}{ Profile P2 - dystrophic clayey Yellow Latosols } \\
\hline A & 4.5 & 3.5 & -1.0 & 0.9 & 0.04 & 0.02 & 0.9 & 6.4 & 1.4 & 8.8 & 11 & 60 & 1.45 \\
\hline $\mathrm{AB}$ & 4.7 & 3.9 & -0.8 & 0.6 & 0.01 & 0.01 & 0.6 & 2.6 & 0.9 & 4.2 & 15 & 59 & 0.70 \\
\hline BA & 5.0 & 4.0 & -1.0 & 0.6 & 0.00 & 0.00 & 0.6 & 2.1 & 0.7 & 3.4 & 17 & 55 & 0.57 \\
\hline Bw1 & 5.0 & 4.1 & -0.9 & 0.5 & 0.00 & 0.00 & 0.5 & 1.5 & 0.6 & 2.5 & 18 & 56 & 0.40 \\
\hline Bw2 & 4.9 & 4.2 & -0.6 & 0.7 & 0.00 & 0.00 & 0.7 & 1.4 & 0.5 & 2.6 & 26 & 44 & 0.46 \\
\hline \multicolumn{14}{|c|}{ Profile P3 - dystrophic clayey Yellow Latosols } \\
\hline A & 4.8 & 3.5 & -1.3 & 0.7 & 0.03 & 0.03 & 0.8 & 8.4 & 1.8 & 10.9 & 7 & 70 & 1.72 \\
\hline $\mathrm{AB}$ & 5.2 & 4.0 & -1.2 & 0.6 & 0.01 & 0.01 & 0.6 & 4.3 & 1.1 & 6.0 & 10 & 64 & 0.80 \\
\hline BA & 5.4 & 4.1 & -1.3 & 0.7 & 0.00 & 0.01 & 0.7 & 2.0 & 0.8 & 3.5 & 20 & 53 & 0.64 \\
\hline Bw1 & 5.5 & 4.2 & -1.4 & 0.7 & 0.00 & 0.00 & 0.7 & 1.5 & 0.6 & 2.9 & 25 & 45 & 0.53 \\
\hline Bw2 & 5.4 & 4.3 & -1.1 & 0.6 & 0.00 & 0.00 & 0.6 & 1.8 & 0.7 & 3.0 & 21 & 51 & 0.56 \\
\hline
\end{tabular}

${ }^{1} \mathrm{CEC}$ - cation exchange capacity; ${ }^{2} \mathrm{Ba}$ sat. - base saturation; ${ }^{3} \mathrm{~m}$ - Aluminum saturation; ${ }^{4} \mathrm{TOC}$ - Total organic carbon.

The cation exchange capacity (CEC) decreased with depth, following the reductions on $\mathrm{H}^{+}$ and $\mathrm{Al}^{3+}$. The OC content contributed to the higher $\mathrm{CEC}$ in A horizon, as the $\mathrm{pH}-$ dependent charges in these soils are derived from organic matter (BALDOTTO; VELLOSO, 2014). On the other hand, the predominance of kaolinite in Bw horizons (JACOMINE et al., 1996) decreased CEC. 
The values of $\mathrm{pH}, \mathrm{Ca}^{2+}+\mathrm{Mg}^{2+}, \mathrm{H}^{+}, \mathrm{Al}^{3+}, \mathrm{S}$ and CEC observed in this study were near those reported by Jacomine et al. (1986) for Latosols from Southwestern Piauí. P1 reached the lowest CEC, what might be attributed to its lower contents of clay, conferring to it the lowest clay fraction activity compared to the other profiles, although all of them are classified as low activity clay ( $\mathrm{Tb}$ ). Conversely to the CEC, base saturation (V) increased with depth due to decreased hydrogen throughout the profile; the values of $\mathrm{V}$ characterize these soils as dystrophic. Table 3 shows increasing values of S and CEC along transect, which might be related to growing rates of clay from P1 to P3 (Table 2). Aluminum saturation (m) was stronger in surface horizons, as observed by Ferreira et al. (2010). The TOC for all profiles is more significant in A horizon, which is related to the input of organic matter provided by native vegetation.

Given the chemical characterization, soils presented no acric trait, which is characterized by low CEC, being equal to or less than $1.5 \mathrm{cmol}_{\mathrm{c}} \mathrm{kg}^{-1}$ clay, mainly in subsurface where $\mathrm{pH}$ in $\mathrm{KCl}$ is equal or greater than 5.0 and $\mathrm{pH}$ in $\mathrm{H}_{2} \mathrm{O}$ is often lower or equal to that, resulting in positive or null $\mathrm{pH}$ variation (SANTOS et al., 2013a).

Mineralogical input of clays was essentially from kaolinite, with gibbsite and goethite (Figure 2), i.e., minerals of highly weathered soils being commonly found in latosols (KER, 1998). Soils with proper drainage and suitable climatic conditions, such as those studied here, desilicatization is intense and tending to form less active minerals, such as kaolinite, which are prevalent in Yellow Latosols according to Ker (1998), with gibbsite and goethite contribution. Moreover, the presence of the latter is what gives rise to the yellow color of the analyzed Latosols (KER, 1998).

The kaolinite was identified by peaks at 0.722 and $0.356 \mathrm{~nm}$ that collapsed with heat treatment at $550{ }^{\circ}$ C. Diffraction peaks at 0.485 and $0.437 \mathrm{~nm}$ identified the gibbsite and within basal spacing at $0.416 \mathrm{~nm}$ goethite was identified, being found in samples of natural clay.

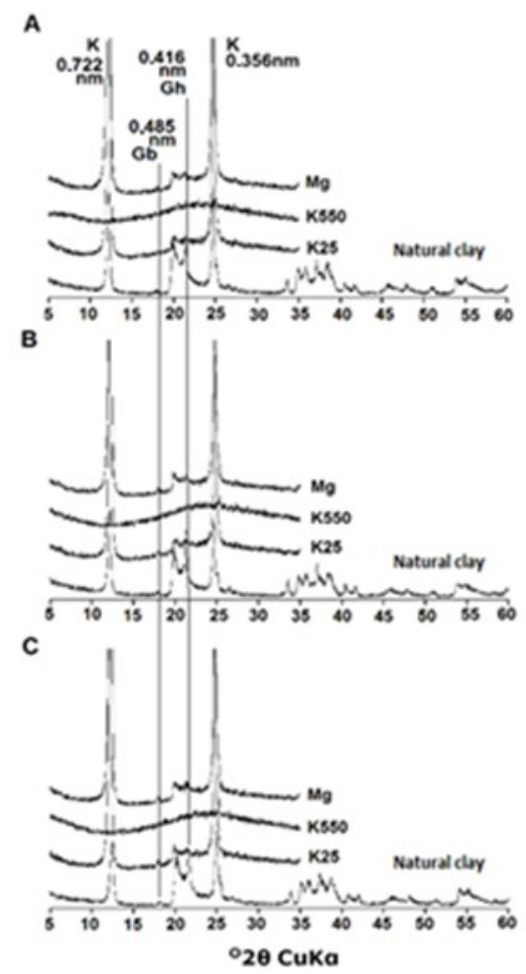

Figure 2. X-ray diffractograma of clay fraction of Bw horizons Yellow Latosols (Oxisols) of Serra do Quilombo (A Profile P1; B - Profile P2; C - Profile P3; K - kaolinite; Gb - gibbsite; Gh - goethite).

Table 4 highlights that contents of $\mathrm{Fe}_{2} \mathrm{O}_{3}$ were low and varied in a much wide range, but are still within the range proposed by Jacomine et al. (1986), who pointed out values below $10 \%$, and also within that advised by Ker (1998) of values under 7\%, for
Yellow Latosols. Similarly, contents of $\mathrm{Al}_{2} \mathrm{O}_{3}$ and $\mathrm{SiO}_{2}$ showed different values within and between profiles, indicating variation in the source material contribution throughout transect, proved by soil texture variation this profile sequence (Table 2). 
Andrade et al. (1997) observed that the source material of Oxisols studied within a toposequence in Amazonas State was heterogeneous, since depth distributions of $\mathrm{SiO}_{2}, \mathrm{Al}_{2} \mathrm{O}_{3}$ and $\mathrm{Fe}_{2} \mathrm{O}_{3}$ were irregular throughout the sequence.

Table 4. Oxides extracted by the sulfuric acid attack, $\mathrm{Ki}$ and $\mathrm{Kr}$ indexes of horizons $\mathrm{A}$ and Bw2 of Yellow Latosols (Oxisols).

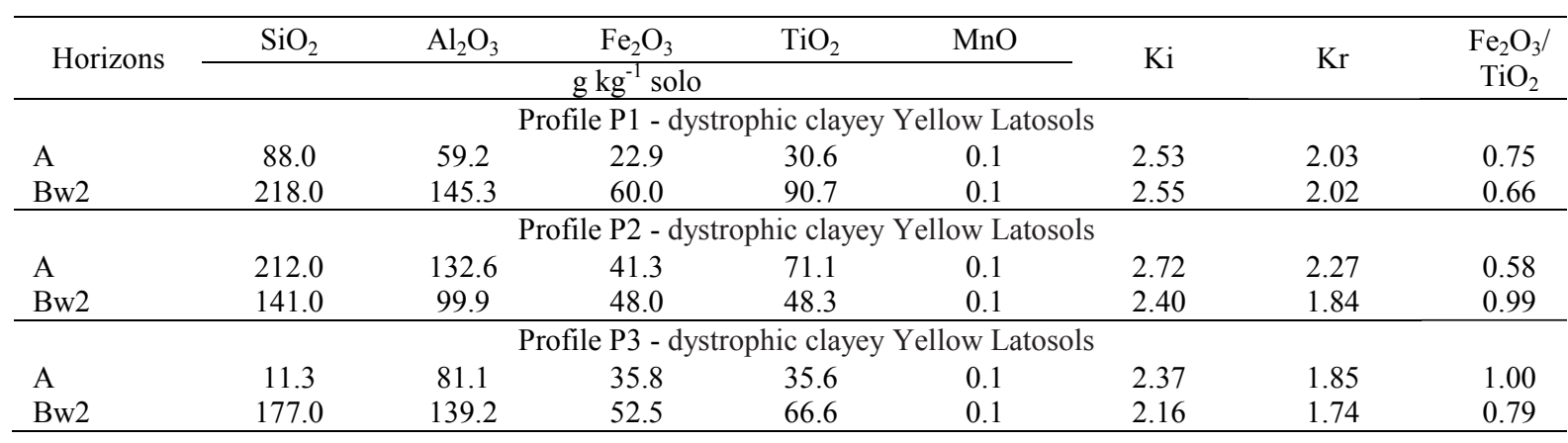

Although resistant to reduction and subsequent removal of iron oxides (Oliveira et al., 1991), $\mathrm{TiO}_{2}$ contents ranged from one horizon to another (A and Bw2) and among profiles. Pereira et al. (2010) stated that $\mathrm{TiO}_{2}$ variations at deeper layers imply in lithologic discontinuity. Even though $\mathrm{MnO}$ contents were quite low without changes among profiles, the results were similar to those reported by Ferreira et al. (2010).

Under the criteria suggested by the SiBCS (SANTOS et al., 2013a), which relate Ki and $\mathrm{Kr}$ with clay fraction mineralogy, profiles have kaolinitic diagnostic horizons, confirming mineralogical analysis, however with $\mathrm{Ki}$ and $\mathrm{Kr}$ values above the expected for $\mathrm{Bw}$ horizons both in $\mathrm{P} 1$ and in $\mathrm{P} 2$ (JACOMINE et al., 1986). As analysis was carried out using ADFE, sulfuric acid extraction might have acted on sand, overestimating $\mathrm{SiO}_{2}$.

\section{CONCLUSIONS}

Soil-landscape relationship in Serra do Quilombo is closely related to geology and geomorphology. Soil characteristics highlight inputs of material from decomposition of the underlying rocks and sediments. The soils in Serra do Quilombo have no difference from those commonly observed on other plateaus of Brazil and classified, according to the Brazilian System of Soil Classification, as dystrophic clayey Yellow Latosols (Oxisols), A moderate, medium to clayey texture, cerrado phase, in flat landscapes.

\section{REFERÊNCIAS}

AGUiAR, R. B DE; GOMES, J. R. DE C. Projeto cadastro de fontes de abastecimento por água subterrânea, estado do Piauí: diagnóstico do município de Bom Jesus. Fortaleza, CE: CPRM Serviço Geológico do Brasil, 2004. 8 p.
ALlEONI, L. R. F.; CAMARGO, O. A. de. Atributos físicos de Latossolos Ácricos do norte paulista. Scientia Agricola, Piracicaba, v. 51, n. 2, p. 321-326, 1994.

ALLEONI, L. R. F.; CAMARGO, O. A. Óxidos de ferro e de alumínio e a mineralogia da fração argila deferrificada de latossolos ácricos. Scientia Agricola, Piracicaba, v. 52, n. 3, p. 416-421, 1995.

ANDRADE, $\mathrm{H}$. et al. Pedogeomorfologia e micropedologia de uma sequência Latossolo - areia quartzosa hidromórfica sobre rochas cristalinas do Estado do Amazonas. Geonomos, Belo Horizonte, v. 5, n. 1, p. 55-66, 1997.

BAldotTO, M. A.; Velloso, A. C. X. Eletroquímica de solos modais e de sua matéria orgânica em ambientes tropicais. Revista Ceres, Viçosa, v. 61, n. 6, p. 1012-1021, 2014.

BROWN, G.; BRINDLEY, G. W. X-ray Diffraction Procedures for clay mineral Identification. In: BRINDLEY, G.W; BROWN, G. (Eds.). Crystal Structures of Clay Minerals and Their X-ray Identification. London: Mineralogical Society, 1980. v. 5 , cap. 5 p. $305-360$.

CAMPOS, M. C. C et al. Relações solo-paisagem em uma litossequência arenito-basalto na região de Pereira Barreto, SP. Revista Brasileira de Ciência do Solo, Viçosa, v. 31, n. 3, p. 519-529, 2007.

CARDUCCI, Carla Eloize et al . Modelagem da curva de retenção de água de Latossolos utilizando a Equação Duplo Van Genuchten. Revista Brasileira de Ciência do Solo, Viçosa, v. 35, n. 1, p. 77-86, 2011.

CASSETI, V. Elementos de Geomorfologia. Goiânia, GO: UFG, 1994. 137 p.

CEDDIA, M. B. et al. Topography and spatial 
variability of soil physical properties Scientia Agricola, Piracicaba, v. 66, n. 3, p. 338-352, 2009.

DONAGEMA, G. K. et al. Manual de métodos de análise de solos. 2. ed. rev. Rio de Janeiro: Embrapa Solos, 2011. 230 p. (Documentos, 132).

FERREIRA, C. A. et al. Genesis and classification of Oxisols in a highland toposequence of the Upper Jequituinhonha Valley (MG). Revista Brasileira de Ciência do Solo, Viçosa, v. 34, n. 1, p. 195-209, 2010.

FUNDAÇÃO CENTRO DE PESQUISAS ECONÔMICAS E SOCIAIS DO PIAUÍ (Fundação CEPRO). Cerrados piauienses. Teresina, PI: CEPRO, 1992. 64 p.

GHIDIN, A. A. et al . Topossequências de Latossolos originados de rochas basálticas no Paraná: II - relação entre mineralogia da fração argila e propriedades físicas dos solos. Revista Brasileira de Ciência do Solo, Viçosa, v. 30, n. 2, p. 307-319, 2006.

INDA JUNIOR, A. V. et al. Variáveis relacionadas à estabilidade de complexos organo-minerais em solos tropicais e subtropicais brasileiros. Ciência Rural, Santa Maria, v. 37, n. 5, p. 1301-1307, 2007.

JACKSON, M. L. Soil chemical analysis Advanced course. Madison: Department of Soil Science, University of Wisconsin. 1979. 895 p.

JACOMINE, P. K. T. et al. Levantamento exploratório. Reconhecimento de solos do Estado do Piaúi. Rio de Janeiro: EMBRAPA-SNLCS/ SUDENE-DRN. 1986. 782 p.

KER, J. C. Latossolos do Brasil: uma revisão. Geonomos, Viçosa, v. 5, n. 1, p. 17-40, 1998.

LIMA NETO, J. A. et al. Caracterização e gênese do caráter coeso em Latossolos Amarelos e Argissolos dos tabuleiros costeiros do estado de Alagoas. Revista Brasileira de Ciência do Solo, Viçosa, v. 33, n. 4, p. 1001-1011, 2009.

MELO, V. F. et al. Caracterização física, química e mineralógica de solos da colônia agrícola do Apiaú (Roraima, Amazônia), sob diferentes usos e após queima. Revista Brasileira de Ciência do Solo, Viçosa, v. 30, n. 6, p. 1039-1050, 2006.

MOORE, D. M.; REYNOLDS, R. C. X-ray diffraction and identification and analysis of clay minerals. Oxford: Oxford University Press, 1989. $332 \mathrm{p}$.

NEIVA, T. D. et al. Anuário Estatístico do Piauí.
Teresina, PI: CEPRO, 2007. 513 p.

OLIVEIRA, J. B.; RESENDE, M.; CURI, N. Caracterização e classificação de Latossolos Variação Una e de solos afins da região de Guaíra, SP. Revista Brasileira de Ciência do Solo, Viçosa: v. 15, n. 2, p. 207-218, 1991.

ORRUTÉA, A. G. et al. Mineralogia e reserva de K de Cambissolos submetidos a diferentes manejos após derrubada e queima da floresta na Amazônia Meridional. Acta Amazônica, Manaus, v. 42, n. 4, p. 461-470, 2012.

PEREIRA, S. A. et al. Análise de componentes principais dos atributos físicos de um Latossolo Vermelho Distrófico típico sob pastagem e mata. Global Science and Technology, Rio Verde, v. 3, n. 2, p. 87-97, 2010.

SANTOS, M. E. C. M.; CARVALHO, M. S. S. Paleontologia das bacias do Parnaíba, Grajaú e São Luís. Rio de Janeiro, RJ: CPRM Serviço Geológico do Brasil - DGM/DIPALE, 2009. 215 p.

SANTOS, H. G. et al. Sistema Brasileiro de Classificação de Solos. 3. ed. Brasília, DF: Embrapa. 2013a. 353 p.

SANTOS, R. D. et al. Manual de descrição e coleta de solo no campo. 6. ed. Viçosa, MG: Sociedade Brasileira de Ciência do Solo, 2013b. 100 p.

SOUZA, L. D. et al. Avaliação de plantas cítricas, em diferentes profundidades de plantio, em Latossolo Amarelo dos Tabuleiros Costeiros. Revista Brasileira de Fruticultura, Jaboticabal, v. 26, n. 2, 2004, p. 241-244. 